International Research Journal of Management, IT \& Social Sciences
Available online at https://sloap.org/journals/index.php/irjmis/
Vol. 8 No. 1, January 2021, pages: 70-82
ISSN: 2395-7492
https://doi.org/10.21744/irjmis.v8n 1.1116

\title{
The Role of Hedonic Consumption Tendency Mediate the Effect of Fashion Involvement on Impulsive Buying
}

\begin{tabular}{|c|c|}
\hline & $\begin{array}{l}\text { Made Diah Kencana Sari } \\
\text { Ni Nyoman Kerti Yasa }\end{array}$ \\
\hline Article history: & Abstract \\
\hline $\begin{array}{l}\text { Submitted: } 27 \text { November } 2020 \\
\text { Revised: } 18 \text { December } 2020 \\
\text { Accepted: 09 January } 2021 \\
\text { Keywords: } \\
\text { fashion involvement; } \\
\text { hedonic consumption tendency; } \\
\text { impulsive buying; } \\
\text { partial least-square; } \\
\text { products; }\end{array}$ & \multirow{2}{*}{$\begin{array}{l}\text { This study aims to examine the effect of fashion involvement on impulsive } \\
\text { buying mediated by hedonic consumption tendencies. The population in this } \\
\text { study are consumers of ZARA fashion products who have made unplanned } \\
\text { purchases in Kuta, whose numbers cannot be identified (infinite). The number } \\
\text { of respondents involved in this study was } 100 \text { respondents. The data in this } \\
\text { study were obtained from the results of filling out a questionnaire. Further } \\
\text { research data were analyzed using the Partial Least Square (PLS) analysis } \\
\text { technique with the help of the Smart PLs program. Based on the results of the } \\
\text { PLS analysis, the results show that (1) the involvement of fashion has a positive } \\
\text { and significant effect on impulsive buying of Zara's fashion products, (2) The } \\
\text { involvement of fashion has a positive and significant effect on the tendency of } \\
\text { hedonic consumption, (3) The tendency of hedonic consumption has a positive } \\
\text { and significant effect on purchases impulsive fashion products Zara and (4) the } \\
\text { hedonic consumption tendency can mediate the influence of fashion } \\
\text { involvement on impulsive buying. } \\
\text { International research journal of management, IT and social sciences }(\text { C 2021. } \\
\text { This is an open access article under the CC BY-NC-ND license } \\
\text { (https://creativecommons.org/licenses/by-nc-nd/4.0/). }\end{array}$} \\
\hline & \\
\hline \multicolumn{2}{|c|}{$\begin{array}{l}\text { Corresponding author: } \\
\text { Made Diah Kencana Sari, } \\
\text { Faculty of Economics and Business, } \\
\text { Udayana University, Denpasar, Indonesia. } \\
\text { Email address: diahkencana_sari@yahoo.com }\end{array}$} \\
\hline
\end{tabular}

Faculty of Economics and Business, Udayana University, Denpasar, Indonesia Faculty of Economics and Business, Udayana University, Denpasar, Indonesia 
1 Introduction

The changing times and the increasing economic level of society have had a huge influence on the needs of each individual's fashion product. Fashion products are one of the main goals for individuals to visit the mall. Fashion is not only about the clothing industry but as a basic human need. According to Trisnawati (2016), fashion is often synonymous with clothing, even though the real meaning of fashion can include everything related to adornment, style, and dress. Fashion can describe a lifestyle in appearance, as well as a reflection of self or group identity. The development of fashion has many impacts on people's lives, such as increasing consumptive and hedonistic behavior in society. The development of fashion also has a very important impact on a country's economy, such as increasing the number of jobs.

The high demand for fashion products in Indonesia and the important role of fashion in the economy is evidenced by a large number of local entrepreneurs engaged in the fashion business and their large contribution to added value to the economy. Data from the Opus Creative Economy Outlook 2019 released by Bekraf (Creative Economy Agency) shows that the fashion sub-sector in 2016 contributed 18.01\% to Gross Domestic Product (GDP), had 1,230,988 entrepreneurs, and absorbed 4,130,000 workers. work. Based on this data, it can be concluded that the fashion business in Indonesia is a very lucrative business to be developed by both domestic and foreign business players. The number of retailers in the fashion sector is increasing, therefore retailers need to understand the needs and desires of consumers and formulate strategies to retain consumers and attract new consumers (Sudarsono, 2017). Retailers' efforts not only attract consumers to make purchases but also to attract fast decision making in the form of impulsive buyings (Badgaiyan \& Verma, 2014).

Impulsive buying is an important phenomenon for businessmen, especially businesses in the fashion sector, to pay attention to. According to Akyuz (2018), the impulsive buying process starts with product awareness. Individuals begin to browse products without intending to buy, and at the same time, they are exposed to stimuli and feel the urge to buy. Consumers become aware of a need when faced with a stimulus and head straight for the purchase route, bypassing the information search or alternative evaluation stage. Naturally, the post-purchase evaluation step will result in satisfaction or dissatisfaction. Impulsive buyers are motivated to satisfy their pleasure immediately, and this cannot be categorized for one particular product category. So efforts to increase impulsive buying, especially for fashion retail owners are very important to maintain business or excel in the fashion business competition (O'Cass, 2000; Park \& Yoo, 2018).

Khawaja (2018), defines impulsive buying as "buying behavior that is urgent, sudden, and hedonistically complex where the speed of the impulsive decision process hinders wise and deliberate consideration of choices and information." According to Choudhary (2014), impulsive buying occurs when consumers experience a sudden event and often a very strong urge to buy something immediately. Yeboah \& Owusu-Prempeh (2017) state that every purchase decision made in a store is called an impulsive buying. Graa et al. (2014), explain that impulsive buying occurs when individuals are affected by feelings that appear suddenly and sometimes conflict with what they feel.

Impulsive buying can occur because individuals have a hedonic tendency to consume, indirectly when individuals make impulsive buying at that time it can also meet hedonic consumption which tends to be a necessity today (Kacen \& Lee, 2002). Hedonism is a behavior that can be seen from individual activities that lead to the pleasures of life. According to Paramita (2014), a hedonic lifestyle is related to an individual's emotional need for a pleasant and interesting shopping experience. Ismayuni \& Saraswati (2015), stated that the positive energy of consumers appears when the hedonism in themselves is high, they will feel comfortable, happy, happy, and satisfied when going shopping. Vazifehdoost et al. (2014), explain that impulsive buying plays an important role in satisfying hedonic needs. According to Eren et al. (2012), the desire to realize the interests of having fun and seeking pleasure is the main determinant of hedonic value which correlates with a person's impulsive buying tendency. A person with hedonic consumption tendencies often cannot control their buying behavior and buys something they do not need above their financial limits through "urgency" or addiction to spending that they have difficulty controlling (Liu et al., 2020; Alba \& Williams, 2013).

Impulsive buying can occur when a person has a fashion involvement that is based on a tendency to follow fashion Fashion involvement has a direct and indirect effect on impulsive buying. According to O'Cass (2004), fashion involvement is a state of encouragement from passion or interest arising from stimuli or situations, and appearance through the property. Pattipeilohy \& Rofiaty (2013), explained that fashion involvement is the level of individual involvement in fashion products related to the latest clothing trends. Park et al. (2006), explain that consumers who have a high involvement with fashion are likely to buy a fashion product on an impulsive buying scale. The same thing is also expressed by Marianty \& Junaedi (2014), which states that consumers who have high involvement in fashion

Sari, M. D. K., \& Yasa, N. N. K. (2021). The role of hedonic consumption tendency mediate the effect of fashion involvement on impulsive buying. International Research Journal of Management, IT and Social Sciences, 8(1), 70-82. https://doi.org/10.21744/irjmis.v8n1.1116 
allow impulsive buyings of fashion products. According to Dhurup (2014), the involvement of fashion, especially students, has a positive and significant effect on impulsive buying, where students are usually the most active in following fashion developments.

Fashion involvement indirectly influences impulsive buying by increasing the hedonic consumption tendency. According to Liang (2012), with the involvement of fashion a person will feel hedonic value because during the hedonic process, a person will feel entertained and get a lot of information about fashion. The higher a person's fashion involvement, the higher the hedonic value that person feels, especially in the shopping process for fashion products. The direct and indirect influence of fashion's involvement with impulsive buying through hedonic Consumption Tendency shows an indication of the tendency of hedonic consumption as a mediating factor. This is confirmed based on the results of research conducted by Haq et al. (2014), and Korry (2017) which states that hedonic consumption tendency factors such as activities, interests, and interests as well as opinions are positively and significantly related to impulsive buying behavior.

One of the famous fashion retail brands in Bali is Zara, which is located in Kuta, Badung district. ZARA boutique is a retail company that sells fashion and lifestyle products. ZARA boutique is an exclusive outlet because ZARA does not place much importance on the number of products, but rather prioritizes various clothing models and provides trendy clothes. The involvement of fashion can be seen when buying products from the ZARA brand where they are more concerned with quality, models that fit them, and current trends compared to the prices listed. Zara in marketing her products sells accessories of the same quality to complement her clothes. This is one of the differences between Zara and other fashion companies.

In 2019, Zara was ranked 29th on Interbrand's global brand consultancy's list of best global brands. According to Aftab \& Yuanjian (2018), Zara is targeting a broad industrial mass market rather than the luxury segment in this industry. Zara fast fashion emphasizes providing products that contain the latest fashionable and trendy design concepts that are produced in a variety of distinctive styles, materials, colors, and silhouettes with reasonable physical qualities quickly and at very attractive prices. According to Saraswat (2018), Zara's fashion trends are updated in time by closely monitoring fashion shows and translating ideas into updated trendy offerings. Zara's target market consists of customers who are interested in buying trendy clothes and high-end fashion products but are unable to make purchases from existing high-end boutiques.

Zara was chosen in this study because of the application of the fast fashion system, Zara's global popularity, and Zara's target market that can be reached by more people. These three reasons are thought to encourage factors that influence impulsive buyings such as fashion involvement and consumer hedonic Consumption Tendency. Fashion in this study is limited to clothes and accessories that complement the clothes.

This research was conducted because there are different results regarding the relationship between the variables previously described, namely: 1) According to Haq et al. (2014) research, the involvement of fashion does not have a significant direct relationship to impulsive buying. The relationship between fashion involvement with impulsive buying is indirectly mediated by the hedonic consumption tendency variable; 2) Variable hedonic consumption tendency with impulsive buying. According to research by Dhurup (2014) and research Arviansyah et al. (2018), the hedonic consumption tendency does not have a positive and significant effect on impulsive buying. Arviansyah et al. (2018), in their research, states that impulsive buyings are motivated by sudden memories of consumers about certain needs or desired products. So impulsive buying can be increased through self-esteem or a higher propensity to buy instant because other factors also influence instant purchases compared to hedonic consumption tendencies.

Based on the results of the description of the phenomenon and gap research, it is stated that the tendency of hedonic consumption and the involvement of fashion can lead to impulsive buying (Subawa et al., 2020). This study will further explain the relationship between fashion involvement and hedonic consumption tendency with impulsive buying of ZARA fashion products in Kuta.

\section{Literature review \\ Consumer behavior theory}

According to Kotler \& Keller (2008), consumer behavior is a study of how individuals, groups, and organizations choose, buy, use and place goods, services, ideas, or experiences to satisfy their wants and needs. According to Schiffman \& Kanuk (2008), consumer behavior describes how individuals make decisions to use their available resources (time, money, effort) to buy goods related to consumption. Also, from the perspective of the theory of reasoned action, the definition of behavior involves several elements: action, target, and context. 
Fashion involvement

Muruganantham \& Bhakat (2013), state that the involvement of fashion is an internal factor that encourages consumers to buy fashion products. Dewi et al. (2015), stated that fashion involvement can be defined based on a collection of the influence of the diversity of the activities of actors who think that fashion is important. 5 factors influence fashion involvement according to Nandini \& Jeevananda (2012), namely purchasing knowledge, trust, social awareness, materialism, and interest in quality.

\section{Hedonic consumption tendency}

According to Saleem et al. (2012), hedonism can be referred to as an individual trait to engage in activities that produce pleasure. According to Saputri \& Rachmatan (2017), hedonism is a view of life that assumes that people will be happy by seeking happiness as much as possible and avoiding painful feelings as much as possible. Hedonic consumption is a dimension of consumption expressed as happiness, pleasure, sensuality, etc. (Aydin, 2010). The tendency of hedonic consumption can be referred to as an individual trait to engage in activities that produce pleasure while shopping (Saleem et al., 2012).

\section{Impulsive buying}

Khawaja (2018), defines impulsive buying as "urgent, sudden, and hedonistically complex buying behavior where the speed of the impulsive decision process hinders the wise and deliberate consideration of choices and information." Virvilaite \& Saladiene (2012), explains that impulsive buying is based on the symbolic self-completion theory (symbolic self-complement theory). Impulsive buying can be classified into four types according to Stern (in Japarianto \& Sugiharto, 2012), namely Pure Impulse Buying, Reminder Impulse Buying, Suggestion Impulse Buying, and Planned Impulse Buying. According to Coley (2003), the psychological process in impulsive buying consists of two processes, namely the affective process and the cognitive process

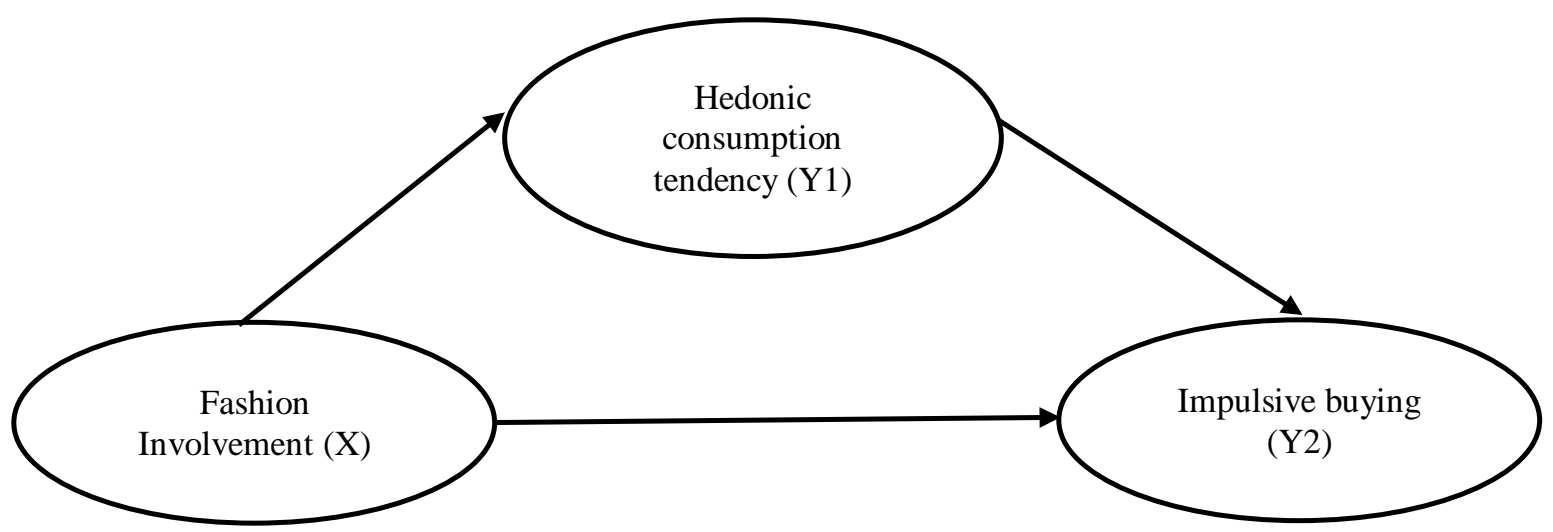

Figure 1. Conceptual framework

Research hypothesis:

H1: Fashion involvement has a positive and significant effect on impulsive buying.

H2: Fashion involvement has a positive and significant effect on hedonic consumption tendency.

H3: The hedonic consumption tendency has a positive and significant effect on impulsive buying.

H4: The hedonic consumption tendency mediates the influence of fashion involvement on impulsive buying.

\section{Materials and Methods}

This research was conducted using an associative approach. This research was conducted in Badung Regency, Kuta District which is a densely populated tourism area and has a lot of access to receive information and there are many shopping centers, especially ZARA products that sell various types of up to date fashion products. Fashion involvement

Sari, M. D. K., \& Yasa, N. N. K. (2021). The role of hedonic consumption tendency mediate the effect of fashion involvement on impulsive buying. International Research Journal of Management, IT and Social Sciences, 8(1), 70-82. https://doi.org/10.21744/irjmis.v8n1.1116 
as the independent variable, Hedonic Consumption Tendency as a mediating variable, and Impulsive Purchasing as the dependent variable.

The population in this study are consumers of ZARA fashion products who have made unplanned purchases in Kuta, whose numbers cannot be identified (infinite). The sampling method used in this study is non-probability sampling. The criteria for determining the sample in this study are that the respondents have been shopping for ZARA fashion products (clothes, pants, shoe bags, accessories) and consumers have bought Zara fashion products in the last 1 year. So the number of samples used was 140 respondents. The data in this study were collected using a survey method using a questionnaire as a data collection tool. The questionnaire distributed to respondents consists of open or closed questions that will be asked for their opinion from the respondent. This study uses Partial Least Square (PLS) with the help of Smart PLS 3 software, PLS was first developed by Herman Wold (Ghozali, 2014).

\section{Results and Discussions}

In this study, the data used are primary data obtained from the results of questionnaires distributed to respondents who have bought ZARA fashion products in Badung Regency. The total number of respondents is 100 people. Characteristics of research respondents are described by presenting their characteristics based on age, class, and gender. In detail, the characteristics of the respondents are presented in Table 1.

Table 1

Characteristics of respondents

\begin{tabular}{|c|c|c|c|c|}
\hline No. & Variable & Classification & Number (people) & Percentage $(\%)$ \\
\hline \multirow{2}{*}{1} & \multirow{2}{*}{ Gender } & Male & 19 & 19 \\
\hline & & Female & 81 & 81 \\
\hline \multirow[t]{2}{*}{ Total } & & & 100 & 100 \\
\hline & \multirow{4}{*}{ Age } & $<18$ у.о & 9 & 9 \\
\hline \multirow{3}{*}{2} & & $18-30$ у.о & 56 & 56 \\
\hline & & $31-50$ у.о & 34 & 34 \\
\hline & & $>50$ у.o & 1 & 1 \\
\hline \multirow[t]{3}{*}{ Total } & & & 100 & 100 \\
\hline & & Private employees & 16 & 16 \\
\hline & & Government employees & 18 & 18 \\
\hline \multirow{4}{*}{3} & Occounation & Entrepreneur & 22 & 22 \\
\hline & (cecupationi & Housewife & 14 & 14 \\
\hline & & Student / Student & 28 & 28 \\
\hline & & Others & 2 & 2 \\
\hline Total & & & 100 & 100 \\
\hline
\end{tabular}

Source: Data processed, 2020

Fashion Involvement is measured in four indicators as illustrated in Table 2 below:

Table 2

Description of respondents' answers to fashion involvement

\begin{tabular}{|c|c|c|c|c|c|c|c|c|c|}
\hline \multirow[t]{2}{*}{ No } & \multirow{2}{*}{ Statement } & \multicolumn{3}{|c|}{$\begin{array}{l}\text { Respondents' } \\
\text { Frequency }\end{array}$} & \multicolumn{2}{|c|}{ Answers } & \multirow{2}{*}{$\begin{array}{l}\text { Total } \\
\text { score }\end{array}$} & \multirow{2}{*}{ Average } & \multirow{2}{*}{ Information } \\
\hline & & 1 & 2 & 3 & 4 & 5 & & & \\
\hline 1 & $\begin{array}{l}\text { I always have an } \\
\text { awareness of the latest } \\
\text { fashion trends }\end{array}$ & 0 & 3 & 13 & 65 & 19 & 400 & 4,00 & Good \\
\hline 2 & $\begin{array}{l}\text { I am always } \\
\text { knowledgeable about the } \\
\text { latest fashion trends }\end{array}$ & 0 & 3 & 11 & 66 & 20 & 403 & 4,03 & Good \\
\hline
\end{tabular}




\begin{tabular}{llllllllll}
\hline 3 & $\begin{array}{l}\text { I always think about the } \\
\text { latest fashion trends }\end{array}$ & 0 & 2 & 17 & 65 & 16 & 395 & 3,95 & Good \\
$4 \quad \begin{array}{l}\text { I always react to the latest } \\
\text { fashion trends }\end{array}$ & 0 & 4 & 16 & 63 & 17 & 393 & 3,93 & Good \\
Fashion Involvement Average & & & & & & & 3,98 & Good \\
\hline
\end{tabular}
Source: Data processed, 2020

The hedonic consumption tendency is measured in four indicators as illustrated in Table 3 below:

Table 3

Description of respondents' answers to hedonic consumption

\begin{tabular}{|c|c|c|c|c|c|c|c|c|c|}
\hline \multirow{2}{*}{ No } & \multirow{2}{*}{ Statement } & \multicolumn{5}{|c|}{ Respondents' Answers Frequency } & \multirow{2}{*}{$\begin{array}{l}\text { Total } \\
\text { score }\end{array}$} & \multirow{2}{*}{ Average } & \multirow{2}{*}{ Information } \\
\hline & & 1 & 2 & 3 & 4 & 5 & & & \\
\hline 1 & $\begin{array}{l}\text { I tend to shop for fashion to } \\
\text { relieve stress }\end{array}$ & 3 & 8 & 33 & 48 & 8 & 350 & 3,50 & Good \\
\hline 2 & $\begin{array}{l}\text { I tend to buy fashion to keep } \\
\text { up with the latest fashions. }\end{array}$ & 1 & 3 & 15 & 69 & 12 & 388 & 3,88 & Good \\
\hline 3 & $\begin{array}{l}\text { I tend to shop for fashion to } \\
\text { make my heart happy }\end{array}$ & 1 & 5 & 37 & 51 & 6 & 356 & 3,56 & Good \\
\hline 4 & $\begin{array}{l}\text { I tend to shop for fashion to } \\
\text { fulfill my desires. }\end{array}$ & 2 & 6 & 30 & 55 & 7 & 359 & 3,59 & Good \\
\hline 5 & $\begin{array}{l}\text { I tend to shop for fashion } \\
\text { quickly }\end{array}$ & 2 & 4 & 23 & 63 & 8 & 371 & 3,71 & Good \\
\hline \multicolumn{7}{|c|}{ Average Hedonic Consumption Tendency } & & 3,65 & Good \\
\hline
\end{tabular}

Source: Data processed, 2020

Impulsive Buying is measured in four indicators as illustrated in Table 4 below:

Table 4

Description of Respondents' Answers to Impulsive buyings

\begin{tabular}{|c|c|c|c|c|c|c|c|c|c|}
\hline \multirow[b]{2}{*}{ No } & \multirow{2}{*}{ Statement } & \multicolumn{5}{|c|}{ Respondents' Answers Frequency } & \multirow{2}{*}{$\begin{array}{l}\text { Total } \\
\text { score }\end{array}$} & \multirow{2}{*}{ Average } & \multirow{2}{*}{ Informatior } \\
\hline & & 1 & 2 & 3 & 4 & 5 & & & \\
\hline 1 & $\begin{array}{l}\text { I feel like most of my } \\
\text { fashion purchases are not } \\
\text { planned from the start }\end{array}$ & 0 & 6 & 34 & 55 & 5 & 359 & 3,59 & Good \\
\hline 2 & $\begin{array}{l}\text { I often buy fashion } \\
\text { products without thinking. }\end{array}$ & 0 & 5 & 25 & 47 & 23 & 388 & 3,88 & Good \\
\hline 3 & $\begin{array}{l}\text { I like to buy fashion } \\
\text { products spontaneously }\end{array}$ & 0 & 5 & 26 & 46 & 23 & 387 & 3,87 & Good \\
\hline 4 & $\begin{array}{l}\text { I tend to be obsessed with } \\
\text { spending the money I } \\
\text { bring in part or all of it on } \\
\text { fashion products. }\end{array}$ & 0 & 27 & 37 & 25 & 11 & 320 & 3,20 & Enough \\
\hline 5 & $\begin{array}{l}\text { I tend to buy fashion } \\
\text { products even though I } \\
\text { don't need them }\end{array}$ & 0 & 5 & 35 & 54 & 6 & 361 & 3,61 & Good \\
\hline \multicolumn{2}{|c|}{ Impulsive buying Average } & & & & & & & 3,64 & Good \\
\hline
\end{tabular}

Based on the number of indicators in each of these variables and based on the design of the hypothesis put forward in this study, the PLS model specifications to be estimated in this study are as follows:

Sari, M. D. K., \& Yasa, N. N. K. (2021). The role of hedonic consumption tendency mediate the effect of fashion involvement on impulsive buying. International Research Journal of Management, IT and Social Sciences, 8(1), 70-82. https://doi.org/10.21744/irjmis.v8n1.1116 


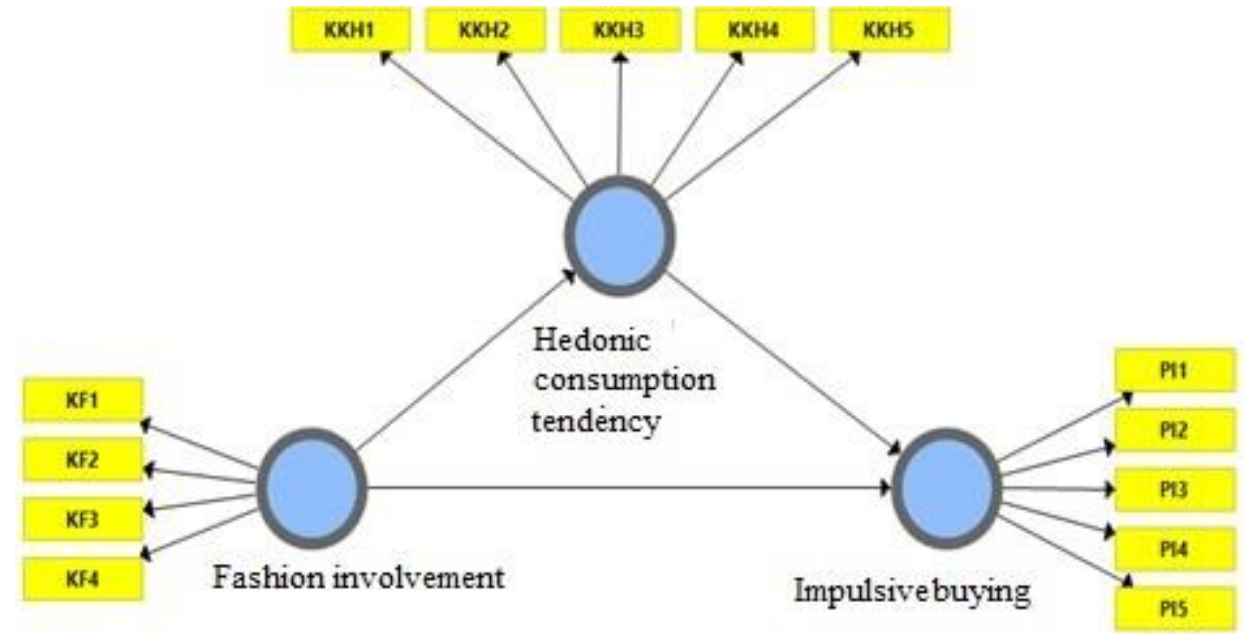

Figure 2. PLS model specifications

The stages in this PLS analysis include the outer model testing phase and the inner model testing phase. The outer model testing phase is used to test the validity and reliability of all indicators in measuring the construct, while the inner model testing is used to test the research hypothesis. The following are all stages in the PLS analysis:

\section{Outer Model Testing}

The testing phase of the measurement model includes testing Convergent Validity, Discriminant Validity, and Composite Reliability.

a) Convergent Validity Testing

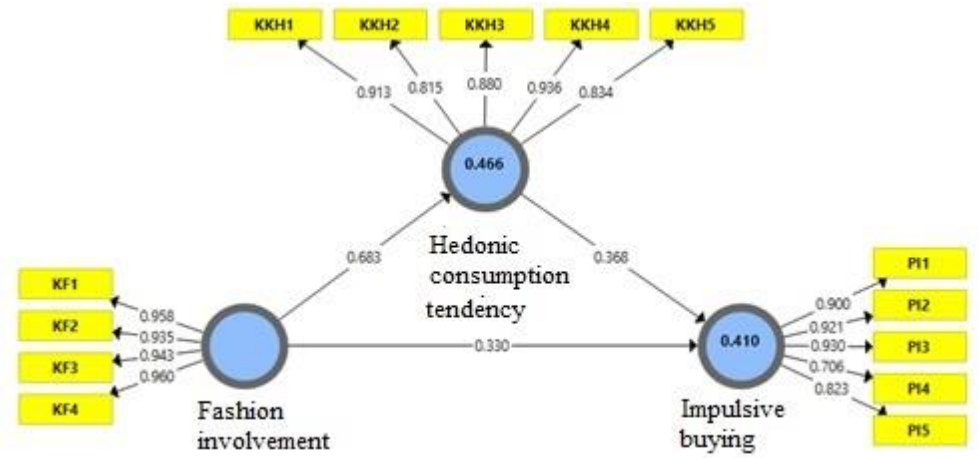

Figure 3. PLS model estimation results with algorithm technique

Based on the estimation results of the PLS model in the image above, it can be seen that all indicators in each construct have a loading factor value above 0.7 so that the PLS model is declared to have met the convergent validity requirements.

b) Discriminant Validity Testing 
Table 5

Results of the fornell larcker method of discriminant validity test

\begin{tabular}{llll}
\hline & Fashion Involvement & Hedonic Consumption Tendency & Impulsive Buying \\
\hline Fashion Involvement & $\mathbf{0 . 9 4 9}$ & & \\
Hedonic Consumption Tendency & 0.683 & $\mathbf{0 . 8 7 7}$ & \\
Impulsive Buying & 0.581 & 0.593 & $\mathbf{0 . 8 6 0}$ \\
\hline
\end{tabular}

Based on the table above, it can be concluded that all the indicators and constructs in the PLS model have met the required discriminant validity criteria.

c) Composite Reliability Testing

Table 6

Composite Reliability Test Results

\begin{tabular}{lll}
\hline Construct & Cronbach's Alpha & Composite Reliability \\
\hline Fashion Involvement & 0.963 & 0.973 \\
Hedonic Consumption Tendency & 0.924 & 0.943 \\
Impulsive Buying & 0.910 & 0.934 \\
\hline
\end{tabular}

Based on the results of the analysis in the table above, the Cronbach's alpha value of all constructs has exceeded 0.7 which means that by looking at the Cronbachs alpha value of each construct, all constructs have met the required reliability criteria. The composite reliability value of all constructs has also exceeded 0.7 , this indicates that all constructs have met the required reliability.

Inner model testing

The inner model test includes the direct effect significance test, the indirect effect test, and the measurement of the influence of each exogenous variable on the endogenous variable.

a) The goodness of fit model test

Table 7

The goodness of fit Model

\begin{tabular}{lll}
\hline & Saturated Model & Estimated Model \\
\hline SRMR & 0.068 & 0.068 \\
& Saturated Model & Estimated Model \\
SRMR & 0.068 & 0.068 \\
\hline
\end{tabular}

Because the SRMR model value is good in the estimated model below 0.08, the PLS model estimated in this study is declared a perfect fit so it is feasible to use it to test the research hypothesis.

Sari, M. D. K., \& Yasa, N. N. K. (2021). The role of hedonic consumption tendency mediate the effect of fashion involvement on impulsive buying. International Research Journal of Management, IT and Social Sciences, 8(1), 70-82. https://doi.org/10.21744/irjmis.v8n1.1116 
b) Direct Effect Testing

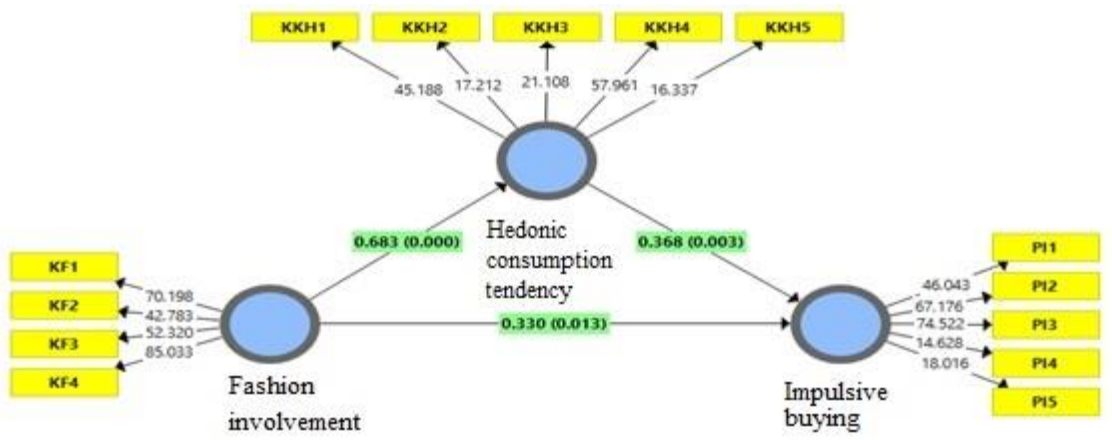

Figure 4. Estimation results of the PLS Bootstrapping model

Based on the estimation results of the PLS model with the bootstrapping technique above, it can be seen that all paths are significant because the $\mathrm{p}$-value of all paths is $<0.05$.

c) Indirect Effect Testing

Table 8

Results of Indirect Effect Testing

\begin{tabular}{llllll}
\hline & $\begin{array}{l}\text { Original } \\
\text { Sample } \\
(\mathrm{O})\end{array}$ & $\begin{array}{l}\text { Sample } \\
\text { Mean } \\
(\mathrm{M})\end{array}$ & $\begin{array}{l}\text { Standard } \\
\text { Deviation } \\
(\mathrm{STDEV})\end{array}$ & $\begin{array}{l}\text { T Statistics } \\
(|\mathrm{O} / \mathrm{STDEV}|)\end{array}$ & P Values \\
\hline $\begin{array}{l}\text { Fashion Involvement -> } \\
\begin{array}{l}\text { Hedonic Consumption } \\
\text { Tendencies -> Impulsive } \\
\text { Buying }\end{array}\end{array}$ & 0.251 & 0.260 & 0.090 & 2.794 & $\mathbf{0 . 0 0 5}$ \\
\hline
\end{tabular}

Because the $\mathrm{p}$-value $<0.05$, $\mathrm{T}$ statistic $>1.65$, and the path coefficient is positive, it can be concluded that the hedonic consumption tendency can mediate the influence of fashion involvement on impulsive buying.

d) Coefficient of Determination

Table 9

Coefficient of Determination

\begin{tabular}{lll}
\hline & R Square & R Square Adjusted \\
\hline $\begin{array}{l}\text { Hedonic } \\
\begin{array}{l}\text { Consumption } \\
\text { Tendency }\end{array}\end{array}$ & 0.466 & 0.460 \\
\hline Impulsive Buying & 0.410 & 0.398 \\
\hline
\end{tabular}

Based on the results of the analysis in the table above, the analysis results show that the $\mathrm{R}$ square value of the hedonic consumption tendency is 0.466 , this indicates that the influence of fashion involvement on the hedonic consumption tendency is $46.6 \%$. Furthermore, in the impulsive buying variable, the coefficient of determination obtained is 0.410 , this indicates that $41 \%$ of the variance of consumer impulsive buyings of Zara fashion products is influenced by Fashion involvement and the hedonic consumption tendency of buyers. 
Hypothesis test

Table 10

Summary of hypothesis testing results

\begin{tabular}{|c|c|c|c|c|c|}
\hline No & Hypotheses & Path Coef. & $\begin{array}{l}\text { T- } \\
\text { Statistics }\end{array}$ & $\begin{array}{l}\mathrm{P} \\
\text { Values }\end{array}$ & Conclusion \\
\hline 1 & $\begin{array}{l}\text { Fashion involvement has a positive and } \\
\text { significant effect on impulsive buying }\end{array}$ & 0.330 & 2.484 & 0.013 & Accepted \\
\hline 2 & $\begin{array}{l}\text { Fashion involvement has a positive and } \\
\text { significant effect on hedonic } \\
\text { Consumption Tendency }\end{array}$ & 0.683 & 11.298 & 0.000 & Accepted \\
\hline 3 & $\begin{array}{l}\text { The edonic consumption tendency has a } \\
\text { positive and significant effect on } \\
\text { impulsive buying }\end{array}$ & 0.368 & 3.006 & 0.003 & Accepted \\
\hline 4 & $\begin{array}{l}\text { Hedonic consumption tendency can } \\
\text { mediate the influence of fashion } \\
\text { involvement on impulsive buying }\end{array}$ & 0.251 & 2.794 & 0.005 & Accepted \\
\hline
\end{tabular}

Source: Data Processing Results (2020)

Hypothesis 1 in this study suspects that fashion has a positive and significant influence on impulsive buying. Hypothesis 2 in this study suspects that fashion has a positive and significant influence on hedonic Consumption Tendency. Hypothesis 3 in this study suspects that there is a positive and significant influence on the tendency of hedonic consumption to impulsive buying. Hypothesis 4 in this study assumes that hedonic consumption tendencies can mediate the influence of fashion involvement on impulsive buying.

Based on the results of testing the hypothesis, it was found that the variable fashion involvement has a positive influence on impulsive buying. The higher knowledge of fashion, the higher the involvement of one's fashion. The high involvement of a person's fashion also affects the desire to show one's existence and encourages impulsive buying if there are attractive and contemporary fashion products like Zara's offer through the principle of fast fashion. The results of this study are from the results of research by Hermanto (2016) and Ahmad et al. (2019), who found that the involvement of fashion has a positive and significant effect on impulsive buying.

Fashion involvement has a positive effect on hedonic Consumption Tendency. That is, the higher a person's fashion involvement, the higher the hedonic value that person feels, especially in the shopping process for fashion products. The results of this study are by the results of a research according to Pattipeilohy \& Rofiaty (2013), who found that the higher the level of involvement with fashion products, the higher the hedonism of consumers to buy fashion products because it is supported by the habit of having clothes with the latest models that are more than one item, thus making consumers more hedonistic when shopping.

The tendency of hedonic consumption has a positive effect on impulsive buying, which means that the higher the tendency for one's hedonic consumption to be the higher the person's tendency to make impulsive buying. The results of this study are consistent with the results of research by Yistiani et al. (2012) and Pattipeilohy \& Rofiaty (2013) who found that hedonism will cause consumers to make impulsive buying to buy fashion products because they find the latest fashion products.

The tendency of hedonic consumption can mediate the influence of fashion involvement on impulsive buying, which means that the higher one's fashion involvement, the higher one's hedonic consumption tendency. The results of this study are by the results of research conducted by Korry (2017), which states that hedonism mediates the influence of fashion involvement on impulsive buying. The higher the consumer involvement, the higher the hedonism attitude, so that unplanned purchases will occur more frequently.

\section{Conclusion}

From the results of data analysis, hypothesis testing, and discussion, it can be concluded from this study as follows: 1) Fashion involvement has a positive and significant effect on impulsive buying of Zara fashion products, this shows that the higher the involvement of consumer fashion, the higher the tendency of consumers to do impulsive buyings of Zara fashion products. 2) The involvement of fashion has a positive and significant effect on the tendency of hedonic

Sari, M. D. K., \& Yasa, N. N. K. (2021). The role of hedonic consumption tendency mediate the effect of fashion involvement on impulsive buying. International Research Journal of Management, IT and Social Sciences, 
consumption, this shows that the higher the involvement of consumer fashion, the higher the tendency of consumers to engage in hedonic consumption. 3) The hedonic consumption tendency has a positive and significant effect on impulsive buying of Zara fashion products, this shows that the higher the hedonic consumption tendency of consumers, the higher the tendency of consumers to make impulsive buying of Zara fashion products. 4) The tendency of hedonic consumption can mediate the influence of fashion involvement on impulsive buying. This means that the high involvement of consumer fashion will increase the tendency of hedonic consumption which in turn will increase the tendency of consumers to make impulsive buying of Zara products.

Based on the results and discussion and conclusions in this study, some suggestions can be given in this study, namely: 1) For companies: Zara Stores need to increase the fashion involvement of their potential consumers, such as by increasing interactions with potential consumers on social media. Zara shops need to provide education or information about the latest fashion trends through their social media. To increase the tendency of hedonic consumption, you can offer discounts, offer exclusive products, and offer a comfortable and pleasant shop atmosphere to satisfy the desires of someone who has a hedonic consumption tendency. 2) For further research: The results of the analysis show that there are still many factors outside the involvement of fashion and hedonic consumption tendencies that affect impulsive buyings such as store atmosphere, use of credit cards, discounts, and use of social media as a means of education and interacting with consumers. Furthermore, it is hoped that it can involve variables outside of these two factors so that it can provide additional insight to fashion producers regarding what factors will influence impulsive product purchases.

\section{Conflict of interest statement}

The authors declared that they have no competing interests.

\section{Statement of authorship}

The authors have a responsibility for the conception and design of the study. The authors have approved the final article.

\section{Acknowledgments}

We are grateful to two anonymous reviewers for their valuable comments on the earlier version of this paper. 


\section{References}

Aftab, M. A., Yuanjian, Q., Kabir, N., \& Barua, Z. (2018). Super responsive supply chain: The case of Spanish fast fashion retailer Inditex-Zara. International Journal of Business and Management, 13(5), 212.

Ahmad, M. B., Ali, H. F., Malik, M. S., Humayun, A. A., \& Ahmad, S. (2019). Factors affecting impulsive buying behavior with mediating role of positive mood: An empirical study. European Online Journal of Natural and Social Sciences, 8(1), pp-17.

Akyuz, A. (2018). Determinant factors influencing impulse buying behavior of Turkish customers in supermarket setting. International Journal of Research in Business and Social Science (2147-4478), 7(1), 1-10.

Alba, J. W., \& Williams, E. F. (2013). Pleasure principles: A review of research on hedonic consumption. Journal of consumer psychology, 23(1), 2-18. https://doi.org/10.1016/j.jcps.2012.07.003

Arviansyah, Dhaneswara, A. P., Hidayanto, A. N., \& Zhu, Y. Q. (2018). Vlogging: Trigger to Impulse Buying Behaviors. In PACIS (p. 249).

Aydin, S. (2010). A Study on Differentation of Hedonic Shopping in Respect of Gender, Income and Size of Settlement. Süleyman Demirel Üniversitesi İ̈BF Dergisi.

Badgaiyan, A. J., \& Verma, A. (2014). Intrinsic factors affecting impulsive buying behaviour-Evidence from India. Journal of Retailing and consumer services, 21(4), 537-549. https://doi.org/10.1016/j.jretconser.2014.04.003

Choudhary, S. (2014). Study of impulse buying behavior of consumers. International Journal of Advance Research in Computer Science and Management Studies, 2(9), 1-4.

Coley, A., \& Burgess, B. (2003). Gender differences in cognitive and affective impulse buying. Journal of Fashion Marketing and Management: An International Journal.

Dewi, N. R. (2015). Pengaruh Fashion Involvemet Dan Kecenderngan Hedonic Consumption Dengan Mediator Emosi Positif Terhadap Pembelian Impulsif Berorientasi Fashion (Survei Pada Pembeli Pakaian Di Mal Olympic Garden Kota Malang). Jurnal Administrasi Bisnis, 26(2).

Dewi, P. D. P., \& Millanyani, H. (2015). Pengaruh Dimensi Motivasi Belanja Hedonis Terhadap Impulse Buying Konsumen Online Store Di Instagram (studi Pada Mahasiswa Di Jakarta). eProceedings of Management, 2(2).

Dhurup, M. (2014). Impulsive fashion apparel consumption: the role of hedonism, fashion involvement and emotional gratification in fashion apparel impulsive buying behaviour in a developing country. Mediterranean Journal of Social Sciences, 5(8), 168-168.

Eren, S. S., Eroğlu, F., \& Hacioglu, G. (2012). Compulsive buying tendencies through materialistic and hedonic values among college students in Turkey. Procedia-Social and Behavioral Sciences, 58, 1370-1377. https://doi.org/10.1016/j.sbspro.2012.09.1121

Ghozali, I. (2014). Metode Alternatif Dengan Partial Least Square (PLS) dengan Program SmartPLS 3.0.

Graa, A., Dani-Elkebir, M., \& Bensaid, M. (2014). The impact of environmental factors on impulse buying behavior using the Mehrabian and Russell's framework. Leonardo Journal of Sciences, 13(24), 101-114.

Haq, M., Khan, N. R., \& Ghouri, A. M. (2014). Measuring the mediating impact of hedonic consumption on fashion involvement and impulse buying behavior. Indian Journal of Commerce \& Management Studies, 5(3), 50-57.

Hermanto, E. Y. (2016). Pengaruh Fashion Involvement Terhadap Impulse Buying Behaviour Masyarakat Surabaya Dengan Hedonic Shopping Motivation Dan Positive Emotion Sebagai Variabel Intervening Pada Merek Zara. Jurnal Manajemen Pemasaran, 10(1), 11-19.

Ismayuni, I., \& Saraswati, T. G. (2015). Pengaruh Emosi Positif, keterlibatan Pada Fashion Dan Kecenderungan Konsumsi Secara Hedonis Terhadap Perilaku Pembelian Impulsif Pada Konsumen Brand Fashion Nike.(studi Pada Pengunjung Nike Store Bandung). eProceedings of Management, 2(3).

Japarianto, E., \& Sugiharto, S. (2012). Pengaruh shopping life style dan fashion involvement terhadap impulse buying behavior masyarakat high income surabaya. Jurnal Manajemen Pemasaran, 6(1), 32-41.

Kacen, J. J., \& Lee, J. A. (2002). The influence of culture on consumer impulsive buying behavior. Journal of consumer psychology, 12(2), 163-176. https://doi.org/10.1207/S15327663JCP1202_08

Khawaja, L. 2018. Factors Influencing Consumer Buying Behavior toward Impulse Buying. The International Journal of Business \& Management. 6(6).

Khokhar, A., Ahmed, A., Rashid, K., \& Qureshi, J. A. (2018). Males As Impulsive Buyers: How Do They Get Affected?. Journal of Organizational Behavior Research, 3(2), 173-188.

Korry, P. D. P., \& Dwiya, K. G. S. (2017). Pengaruh hedonisme dalam memediasi fashion involvement terhadap perilaku impulse buying pada generasi milenial di Bali. Jurnal Ilmiah Manajemen dan Bisnis, 2(2), 311-323.

Kotler, P., \& Keller, K. L. (2008). Manajemen Pemasaran, Jilid 1, Penerbit Erlangga.

Sari, M. D. K., \& Yasa, N. N. K. (2021). The role of hedonic consumption tendency mediate the effect of fashion involvement on impulsive buying. International Research Journal of Management, IT and Social Sciences, 8(1), 70-82. https://doi.org/10.21744/irjmis.v8n1.1116 
Liang, Y. P. (2012). The relationship between consumer product involvement, product knowledge and impulsive buying behavior. Procedia-Social and Behavioral Sciences, 57, 325-330. https://doi.org/10.1016/j.sbspro.2012.09.1193

Liu, F., Lim, E. T., Li, H., Tan, C. W., \& Cyr, D. (2020). Disentangling utilitarian and hedonic consumption behavior in online shopping: An expectation disconfirmation perspective. Information \& Management, 57(3), 103199. https://doi.org/10.1016/j.im.2019.103199

Marianty, R., \& Junaedi, M. F. S. (2014). Pengaruh Keterlibatan Fashion Emosi Positif Dan Kecenderungan Konsumsi Hedonik Terhadap Pembelian Impulsif. Jurnal Magister Manajemen, 1-15.

Muruganantham, G., \& Bhakat, R. S. (2013). A review of impulse buying behavior. International Journal of Marketing Studies, 5(3), 149.

Nandini, R. Jeevananda.(2012). To Study the Factors of Consumer Involvement in Fashion Clothing. International Journal of Science and Research (IJSR), 9-13.

O'Cass, A. (2000). An assessment of consumers product, purchase decision, advertising and consumption involvement in fashion clothing. Journal of Economic Psychology, 21(5), 545-576. https://doi.org/10.1016/S01674870(00)00018-0

O'Cass, A. 2004. Fashion clothing consumption: antecedents and consequences of fashion clothing involvement. European Journal of Marketing, 38(7):869-882.

O'Cass, A. (2004). Fashion clothing consumption: antecedents and consequences of fashion clothing involvement. European Journal of Marketing.

Paramita, A. O. (2014). Pengaruh Nilai Belanja Hedonis Terhadap Pembelian Impulsif Pada Toko Online Dengan Emosi Positif Sebagai Variabel Perantara (Studi Pada Mahasiswa/i Program Strata-1 Angkatan 2011/2012 Jurusan Administrasi Bisnis Fakultas Ilmu Administrasi Universitas Bra. Jurnal Administrasi Bisnis, 8(2).

Park, E. J., Kim, E. Y., \& Forney, J. C. (2006). A structural model of fashion-oriented impulse buying behavior. Journal of Fashion Marketing and Management: An International Journal.

Park, M., \& Yoo, J. (2018). Benefits of mass customized products: moderating role of product involvement and fashion innovativeness. Heliyon, 4(2), e00537. https://doi.org/10.1016/j.heliyon.2018.e00537

Pattipeilohy, V. R., \& Rofiaty, M. S. I. (2013). The Influence of the availability of Money and Time, Fashion Involvement, Hedonic Consumption Tendency and Positive Emotions towards Impulse Buying Behavior in Ambon City (Study on Purchasing Products Fashion Apparel). International Journal of Business and Behavioral Sciences, 3(8), 36-49.

Saleem, M. A., Ali, R. A., \& Ahmad, S. (2012). Post purchase cognitive dissonance: Impact of product involvement, impulse buying and hedonic consumption tendencies. Interdisciplinary Journal of Contemporary Research in Business, 4(5), 1051-1060.

Saputri, A., \& Rachmatan, R. (2017). Religiusitas dengan gaya hidup hedonisme: sebuah gambaran pada mahasiswa Universitas Syiah Kuala. Jurnal Psikologi, 12(2), 59-67.

Saraswat, S. (2018). Strategies v/s Consumer Perception of Brand Zara-India. IITM Journal of Management and $I T, 9(2), 68-80$.

Schiffman \& Kanuk. (2008). Perilaku konsumen. Edisi 7. Jakarta: Indeks

Subawa, N. S., Widhiasthini, N. W., Pika, P. A. T. P., \& Suryawati, P. I. (2020). Hedonism on the behavior of consumer society as a global cultural transformation. International research journal of management, IT and social sciences, 7(2), 59-70.

Sudarsono, J. G. (2017). Pengaruh visual merchandising terhadap impulse buying melalui positive emotion pada zara surabaya. Jurnal Manajemen Pemasaran, 11(1), 16-25.

Trisnawati, T. Y. (2016). Fashion sebagai bentuk ekspresi diri dalam komunikasi. Jurnal The Messenger, 3(2), 36-47.

Vazifehdoost, H., Rahnama, A., \& Mousavian, S. J. (2014). Evaluation of the influence of fashion involvement, personality characteristics, tendency to hedonic consumption and store environment on fashion-oriented impulse buying. Mediterranean Journal of Social Sciences, 5(16), 223.

Virvilaitè, R., \& Saladienè, V. (2012). Models investigation of factors affecting consumer impulsive purchase behaviour in retail environment. Economics and Management, 17(2), 664-670.

Yeboah, A., \& Owusu-Prempeh, V. (2017). Exploring the Consumer Impulse Buying Behaviour from a Range of Consumer and Product Related Factors. International Journal of Marketing Studies, 9(2), 146-159.

Yistiani, N. N. M., Yasa, N. N. K., \& Suasana, I. G. K. G. (2012). Pengaruh atmosfer gerai dan pelayanan ritel terhadap nilai hedonik dan pembelian impulsif pelanggan matahari department storeduta plaza di denpasar. Matrik: Jurnal Manajemen, Strategi Bisnis dan Kewirausahaan. 